\title{
14. INTEGRATING GREEN BUILDING APPROACHES TO INTERIOR ARCHITECTURE EDUCATION: A CROSS- CULTURAL STUDY
}

\author{
Şule Taşlı Pektaş, N. Şule Aybar, N. Yaprak Savut, \\ Hunt McKinnon
}

\begin{abstract}
The success of the efforts for green building depends largely on integrating such approaches with building design education. However, most of the existing studies on green building have focused on the technical issues, while its sociocultural and educational aspects have been less examined. In order to alleviate the problem, this paper presents an international workshop that explores how green building design can be taught in a global teamwork project using a green building assessment system, Leadership in Energy and Environmental Design (LEED) checklist as a framework and examples of vernacular architecture as precedents. The results of an empirical survey reveals a gap between students' general learning about green building in a developing and a developed country and suggests that a collaborative project experience may facilitate bridging the gap and exchanging technical and cultural information related to sustainability.
\end{abstract}

Keywords: Green building, Sustainability, Architectural Education, Green building assessment systems, Global teamwork.

\section{INTRODUCTION}

"Green Building" is a term encompassing strategies, techniques and construction products that are less resource-intensive or pollution-producing than regular construction (Hoffman and Henn, 2008). Due to the pressing problems created by the depletion of the earth's resources, environment-friendly design and construction techniques gained interest and several studies on green building have been conducted in academia. However, a review of the existing studies reveals that most of them focused on the technical issues such as development of technical products, systems, and standards, while its educational aspects have been rarely discussed. Furthermore, the majority of the educational studies on green building have been merely descriptive in nature and empirical analyses of students' experiences and preferences have been still lacking.

Many researchers suggested that international studies in green building are essential to understand different contexts involved, exchange ideas, and increase awareness and motivation (O'Reilly and Symko, 2008; Larsson, 2001). Global teamwork can be a means for such collaboration in building design education. Kristof et al. (1995) defines the term "global team" as a temporary, digitally mediated, culturally diverse and geographically distributed group of peers who collaborate in a shared project. Several advantages of using such teams for teaching and learning have been addressed such as sharing a variety of ideas, perspectives and approaches to problem solving, creativity, cognitive and social development, etc. (Karakaya and Pektas, 2007; Pektas, 2007). Reed and Gordon (2000) also states that cross cultural teamwork early in a design process is useful for achieving the successful integration of building, community, natural, and economic systems for sustainable development.
A global teamwork experience on green building among the participants from a developing and a developed country especially deserves attention, since context-specific differences in sustainable design is a newly emerging issue as manifested by the studies of Ali and Al Nsairat (2009), Sathaye, Shukla, and Ravindranath (2006), and Gibberd (2003).

Teaching sustainability requires an understanding that sustainability is not a monolithic concept but a network of ideas. There are several (sometimes controversial) approaches to sustainability and this complexity makes it difficult to define, assess and teach (Stieg, 2006). Green building assessment systems like LEED offer a systematic way of assessing a building's expected level of performance in a number of declared criteria. Most systems, though primarily intended as assessment systems, are also used as design tools enabling designers to review proposals with a green building perspective (Todd et al., 2001). Recently, such systems have also been shown to be useful for supporting green building courses (Ahn et al., 2009). Therefore, in this study, the LEED assessment system was used both as an evaluation tool for the conceptual design projects and as a framework to define and analyze different aspects of green building.

Besides a green building assessment system, principles of vernacular architecture are also interesting to study in a green building context. Guy and Farmer (2001) discuss that eco-technical approaches which prioritize scientific evaluation and technological solutions dominate efforts in sustainable architecture. Eco-cultural approaches, on the other hand, emphasize the peculiarities of place, locality, and an appropriate formal response to climatic and micro-climatic conditions (Guy and 
Farmer, 2001). In collaboration of the participants from a developing and a developed country, a balance of eco-technical and eco-cultural approaches can be sought for and this may encourage exchange of technical and cultural information.

Within this perspective, an international online workshop was conducted as a joint project between Bilkent University (BU), Department of Interior Architecture and Environmental Design, Turkey and East Carolina University (ECU), Department of Interior Design and Merchandising, the US. In this project, the participants were grouped so that each team consisted of both BU and ECU students and the teams were engaged in a conceptual design project in which green and sustainable building requirements were the main concern. Each team was asked to design a self-sufficient living unit for a specific climatic region of Turkey. The students were encouraged to learn about both vernacular architecture and LEED assessment criteria. After the project, a survey was conducted to investigate the participants' learning experiences and opinions about how to integrate green building design in interior architecture curricula. The research questions of the study are listed below:

1. What are students' previous experiences about green building design in interior architecture education?

2. What are students' experiences about green building design in the international workshop?

3. What are students' opinions about how to integrate green building design with interior architecture curricula?

4. Is there any difference between the students from the US and Turkey with respect to the issues studied?

5. What can be the implications of this study for the future efforts to integrate green building approaches with interior architecture education?

The paper is organized in four sections. The first section reviews the current status of green building in interior architecture curricula in the US and Turkey. The second section describes the design and implementation procedures of the international workshop. The empirical survey and its results are explained in the third section. The final section presents the implications of the study and the suggestions for further research.

\section{GREEN BUILDING IN INTERIOR ARCHITEC- TURE CURRICULA IN THE US AND TURKEY}

The importance of education for sustainable development has been recognized internationally. World Commission on Environment and Development which was formed in 1983 published Our Common Future, which is also known as the "Bruntland Report", in 1987. The term sustainable development emanated from this report and gained popularity afterward (Junyent and Gel de Ciurana, 2008). In 1992, Earth Summit by the United Nations stated that "...education is critical for promoting sustainable development and improving the capacity of the people to address environment and development issues" (United Nations 2004, p.1).

On 20 December 2002 at its 57th session, the United Nations General Assembly adopted
Resolution 57/254, to declare the United Nations Decade of Education for Sustainable Development (2005-2014) and the UNESCO became the lead agency (United Nations 2004). The word "sustainability" established as the keyword since then.

Green building emerged as a result of interest in sustainability in the built environment. This approach necessitated a system to define and to measure sustainability within the industry. A green building assessment system attempts to define an evaluation framework for several aspects of green building design and provides the developers with a checklist of criteria by which the greenness of a building can be evaluated. Many countries developed their own green building assessment systems such as Building Research Establishment Environmental Assessment Method (BREEAM) in the UK, Deutsche Gesellschaft für Nachhaltiges Baven (DGNB) in Germany, and LEED in the US.

In parallel with these developments, there have been various efforts to embed sustainable and green building in interior architecture education worldwide, while this paper particularly focuses on the studies in the US and Turkey. The Council of Interior Design Accreditation (CIDA) and the Interior Design Educators Council (IDEC), the two important educational institutions which determine the educational quality in Interior Design programs in the US, declared that they endorsed the inclusion of education for environmental sustainability in interior architecture curricula (Cradle to Cradle Task Force, 2005).

CIDA organizes site visits to the accreditation seeking higher education institutions. The representatives of CIDA examine the evidences of student learning about several standards in a matrix with three levels of knowledge acquisition: "Awareness- familiarity with specified data, and information that is demonstrated either in student work or student interviews. Understanding- a thorough comprehension of concepts and their interrelationships..." (CIDA, 2011, p.9) and "Apply/Able/Ability- competent entry level skills that must be demonstrated in completed student work" (CIDA, 2011, p. 10). In this matrix, CIDA placed the requirement of knowledge in sustainability at 'understanding' level in "Standard 2. Global Perspective for Design" and explained the student learning expectations as: "Student work demonstrates the understanding of: a) the concepts, principles and theories of sustainability as they pertain to building methods, materials, systems, and occupants. ..." (CIDA, 2011, p.13) and 'awareness' level in "Standard 14. Regulations... Student have awareness of a) Sustainability Guidelines ...Examples include LEED, [Collaborative for High Performance Schools] CHPS, Energy Policy Act 2005, California 01350. ..." (CIDA, 2011 , p. 22). The higher education institutions are inviting CIDA voluntarily and as of today, there are 176 universities accredited by CIDA in the US and Canada (CIDA, 2013). One of the higher education institutions offering a BSc degree in Interior Design is the Department of Interior Design and Merchandising at East Carolina University, NC. They received their accreditation in 2009.

Although interior architecture education in Turkey commenced in 1925 and Chamber of Interior Architects was established in 1976, Turkey still does have neither an educational accreditation agency nor an educators' council which enforces the higher education institutions to integrate sustainability to their professional education programs. In 2011, Turkish Chamber of 
Interior Architects became a 'Full Voting Member' of International Federation of Interior Architects/Designers (IFI). The declaration of IFI (2011) states that interior designers and architects should concern about human and environmental ecology as a part of their professional practice. On the other hand, Çevre Dostu Ye Binalar Derneği (CEDBIK) - Association of EnvironmentFriendly Green Buildings - was established to develop a green building assessment system in Turkey in 2007 (CEDBIK, 2007). It is in the process of adapting the requirements of LEED with respect to Turkish building construction standards. However, all of these efforts are at the level of infancy, yet.

\section{DESIGN AND IMPLEMENTATION OF THE INTERNATIONAL WORKSHOP}

Within the above presented framework, an international online workshop enabled collaboration between two interior design programs; one named as $\mathrm{BU}$, and the other named as ECU before. The students from ECU had studied the LEED assessment system in one of their studio courses during the semester before the workshop and had learned how to apply the sustainability points (as of 2009) to their own projects. According to its 2009 version, the LEED assessment system evaluated the buildings as existing and new construction through the following categories: general, sustainable sites, water efficiency, energy and atmosphere, materials and resources, indoor environmental quality, innovation in design, and regional priority. The projects could receive up to total 110 points from these categories. Some of the categories (i.e., sustainable sites, water efficiency, energy and atmosphere, materials and resources, and indoor environmental quality) had mandatory prerequisites in order to get any credit from that category. The workshop was conducted according to the new construction rules standards because the foundation and structure of the building used in conceptual design was given to the students, it required major renovations for adapting to the function and environment.

The academic semester at ECU started during the first week of January whereas the BU students started new semester in the second week of February. The ECU students were informed about the workshop as soon as the classes had started and they started to learn about Universal Design principles and went over the sustainability issues of the built environment during the first four weeks of the semester. Then, BU students started a new semester and were informed about the requirements of the design problem as soon as the semester began. The project was designing a partially self sufficient-living unit in one of the six different climatic regions of Turkey in conformance with LEED 2009 as the green building design criteria. The students were given a hypothetical steel structure which was $36 \mathrm{sq}$. m. and each group was assigned to one of the climatic regions. The climatic regions were specified according to former studies by Sensoy, et al. (2008), Unal, Kindap, and Karaca (2003) as well as Olgyay (1992) as follows:

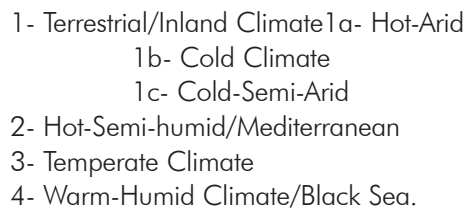

The Moodle learning management system (LMS with its project database, discussion forums, and Wiki), videoconferencing systems (global classroom type and Skype), and Facebook were utilized as communication tools among the student groups of two countries in the study. The "project cloud" provided limitless access to all design-related resources such as the project brief, researches, case studies, guidelines, etc. The instructors hypothesized that a combination of synchronous and asynchronous tools with different representations of project-related knowledge would enhance learning processes.

There were18 ECU students (juniors and seniors taking the Interior Design Studio IV: Universal Design course) and 75 BU students (seniors taking Interior Design Studio: Graduation Project course) who could participate in this workshop. The great difference in numbers of the students was overcome by applying a two phased process. In phase one, there were five students of fifteen teams on the BU side. Each team was asked to develop a conceptual design proposal in response to the brief and to present their ideas in a preliminary jury. Nine teams which were assessed as more comprehensive were selected by the instructors of BU by the end of this phase and introduced to ECU students. In the second phase, each BU team grouped with two ECU students according to their competencies which complement each other.

In the first week of the workshop, an instructor (M.Arch) of BU presented climate-responsive Turkish construction techniques to both groups in the global classroom (Figure 2). The global classroom included two conference rooms in Turkey and in the US with livevideoconferencing systems. Each live-videoconferencing system was of room type and included two large flat screens, cameras, and microphones to communicate to
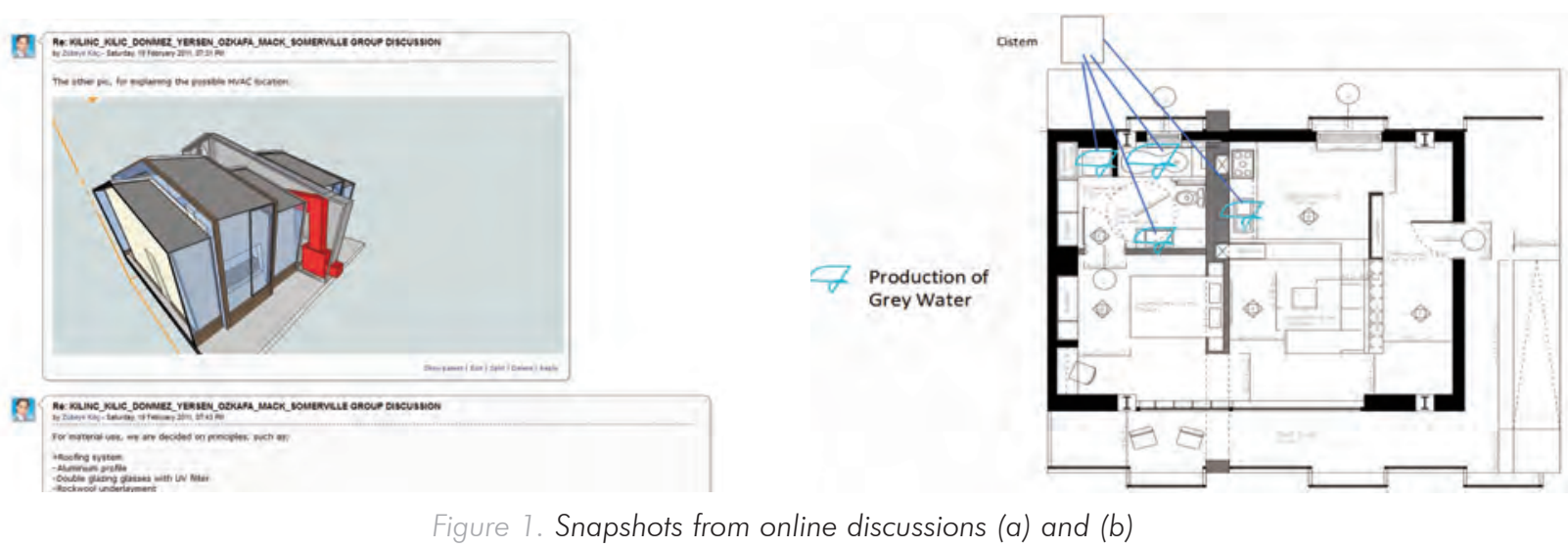

Figure 1. Snapshots from online discussions (a) and (b) 


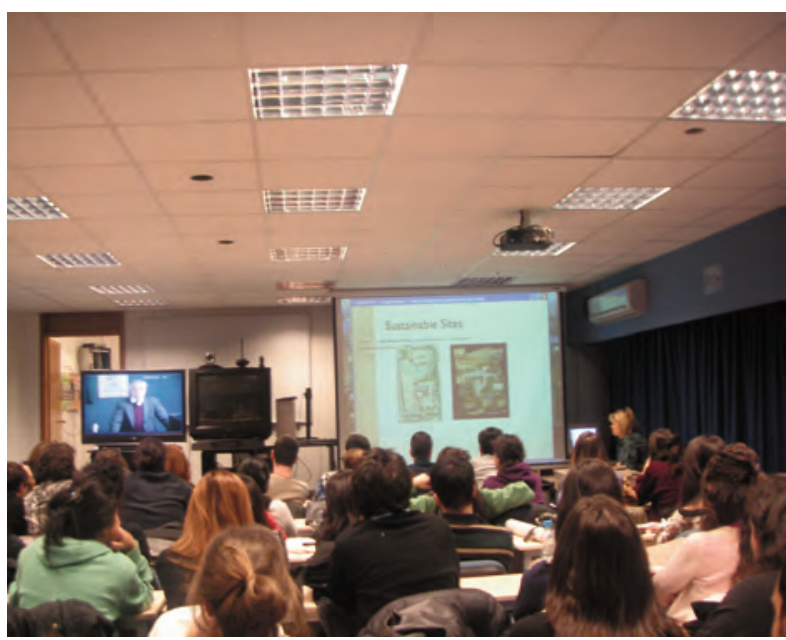

Figure 2. A view of the global classroom

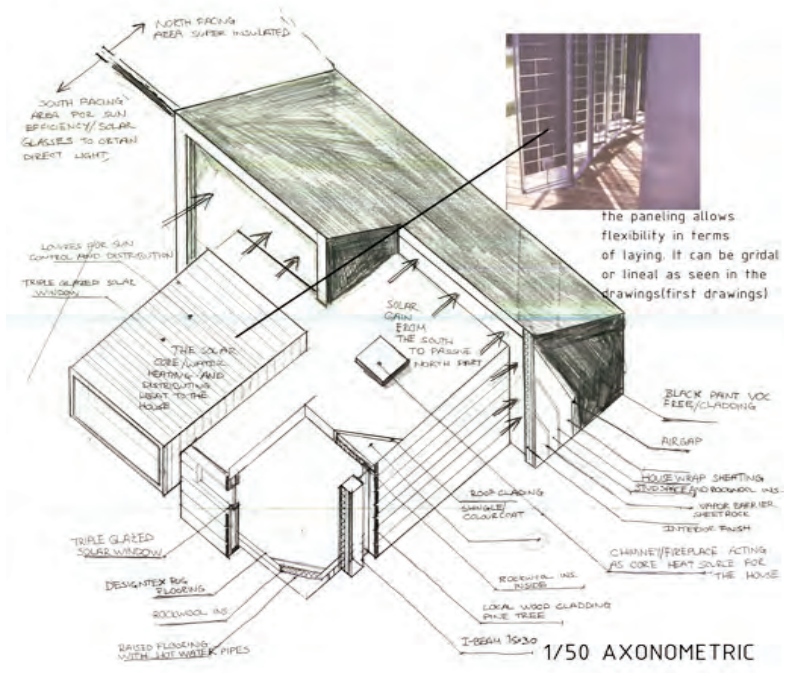

BU students improved their understanding of the LEED system by consulting their teamed ECU friends in a collaborative approach. BU students developed the conceptual designs of the dwellings and sent them to their team mates at ECU. Then, ECU students examined the designs and gave feedback to their team members. Most of the feedback was focusing on the suggestions to get more points on the LEED system by changing the materials used in the structures, changing the locations or sizes of the openings on walls, collecting gray water and reusing it in the unit, etc. The instructors of both universities followed the communication trails and kept on giving critiques on the projects in coordination.

Two video-conference sessions were organized in the fourth and fifth weeks of the workshop successively to carry out the final evaluations of the group projects in an online design studio jury. The BU students presented the projects to both groups in the global classroom and received more feedback from the other teams and instructors. The ECU students made the final presenta-

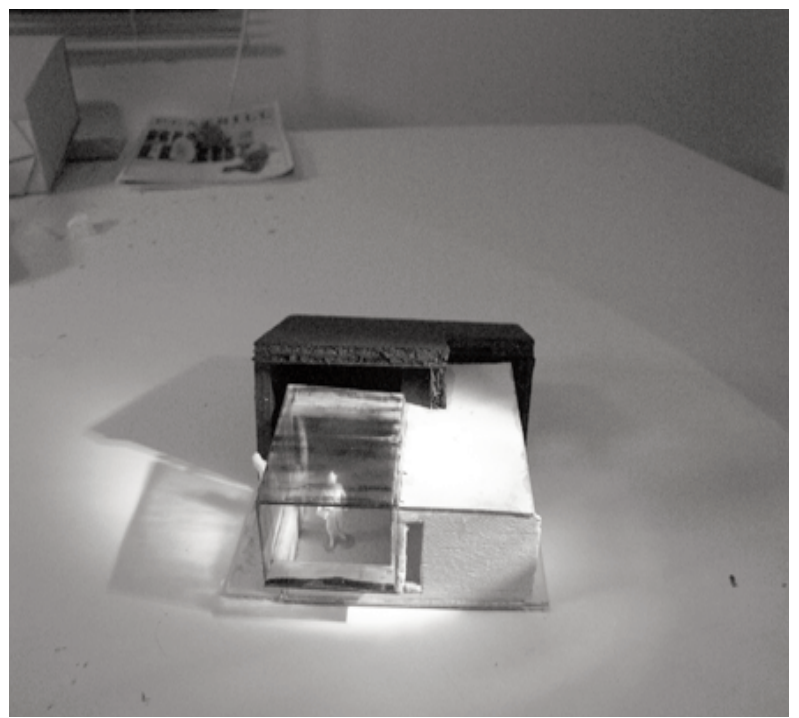

\section{Figure 3. Climate-responsive form finding studies (a) and (b)}

the other similarly equipped conference room. The system provided simultaneous video, voice, and file transmission between the two groups over the Internet and operated in continuous presence mode so that both groups were displayed at the same time. The members of each team met each other during videoconferencing. By the end of the first week of the project, BU students began to share their initial ideas from Phase I with their ECU partners. Students explored and co-constructed design knowledge in the form of online messages, sketches, images, drawings, videos, links to case studies and knowledge repositories, and any other means they proposed. The instructors provided many opportunities for the course-related activities and ensured that students controlled the processes on their own.

The objective of the second week of the workshop was to continue to communicate. An instructor (AIA, LEED AP) of ECU gave a lecture about the LEED assessment system in the global classroom. Two ECU students of the same team helped their group members to improve sustainable design issues of the team's project according to LEED to gain sustainability points. The lectures helped the teams to understand the design problem and the goals of the project. While ECU students learned about Turkish indigenous and traditional construction techniques according to climatic regions, tions one week later and explained how many points each project received for which reasons with respect to the LEED assessment system (Figure 4).

\section{THE EMPIRICAL SURVEY Research Setting and Participants}

To answer the research questions, the authors developed a questionnaire. Some of the questions were adapted from Gurel (2010) and several questions were designed with a particular focus on green building education and LEED criteria. Most of the questions utilized a five-point Likert scale in which higher values indicated a more positive response. The questionnaire was approved by IRB of ECU in April 2011. Sixty-three students participated in the workshop and the questionnaire were available for all of the participants. The students were informed that the survey was conducted for an academic research which was independent from the courses and that their responses to the questions would remain anonymous. Fifty-five of the questionnaires were completed and included in the analysis. Forty-two of them were BU students and 13 of them were ECU students. Forty-five of the participants were female (82\%) and 10 of them were male (18\%). The mean age of the subjects was 22.4 (SD $=1.55)$. 


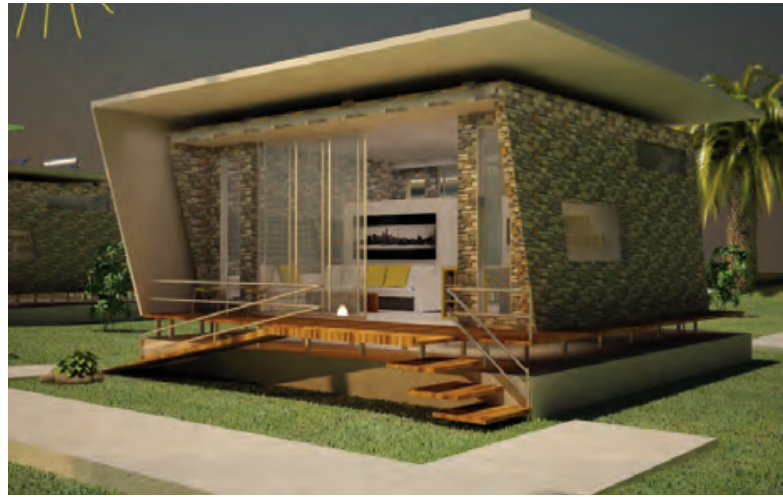

Figure 4. A team's design proposal (a) and its evaluation according to LEED (b)

\section{Analysis and Results}

Students' previous experiences about green building design in interior architecture education

In two questions, the students were asked to indicate how much they learned about green building in other interior architecture courses on a five-point Likert scale (5: "Very much" and 1: "Very little"). Students' answers to this question $(X=3.02, S D=0.94)$ revealed that the mean score was not significantly different from 3 which indicated a medium amount. The participants were also requested to specify how much they learned about main aspects of green building design as defined by LEED criteria in the other courses in interior architecture curricula. Although ECU students' scores were higher than that of BU students for all of the subtitles, the largest difference was found between the two groups in "innovation in design" subtitle. The mean score of ECU students regarding their level of learning in innovation in design $(X=3.92, S D=0.86)$ was significantly higher than that of BU students $(X=3.23, \mathrm{SD}=1.01, t=-2.4, p<$ 0.05). The results are presented in Figure 5.

\section{Students' experiences about green building design in the workshop}

Six questions of the survey focused on students' experiences about green building design in the workshop. Ninety-five percent of the students reported that participating in the workshop stimulated their interest in environmentally responsible design in a great extent $(X=$ $4.12, \mathrm{SD}=0.68, t=11.90, p<0.001)$. They also indicated that participating in the workshop affected the way they would approach to interior architecture $(X=$ $3.71, \mathrm{SD}=0.92, t=11.90, p<0.001)$. The participants were also asked to evaluate their overall learning about green building design in the workshop. The mean score for this question was 4.15 (SD $=0.72, t=$ $11.67, p<0.001$ ) which indicated a significantly pos-

\section{$-28$}

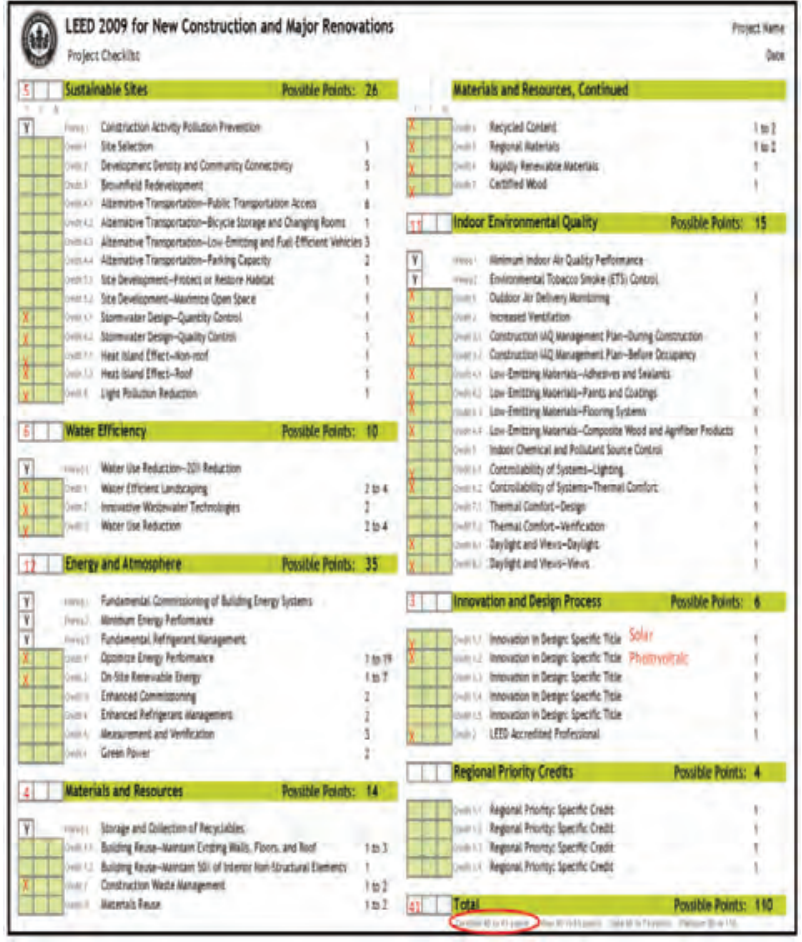

itive response. T test for the comparison of the means showed that students' learning about green building in the workshop was significantly more than that in the other courses $(t=-7.80, p<0.001)$. The students were also asked how much they learned about main aspects of green building design as defined by LEED criteria in the workshop. The results are presented in Figure 6.

To understand the relations between students' evaluation of their learning of green building design aspects in other courses and in the workshop, Pearson $r$

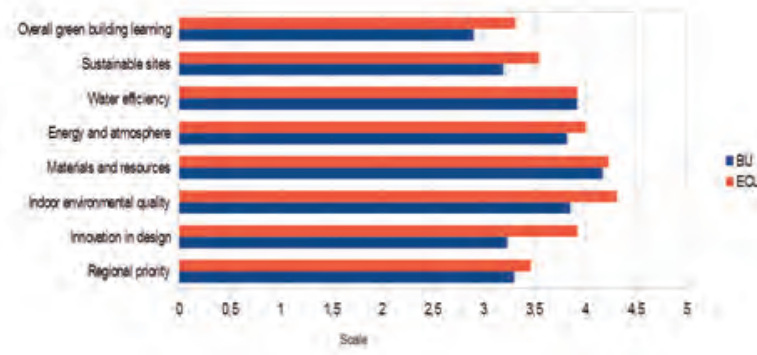

Figure 5. Students' evaluation of their learning of green building design aspects in other courses in interior architecture curricula.

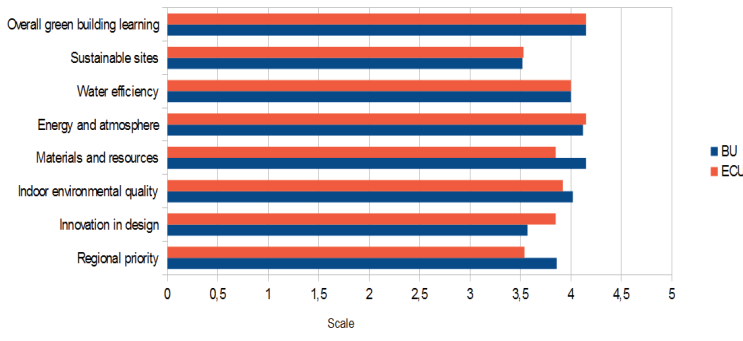

Figure 6. Students' evaluation of their learning of green building design aspects in the workshop. 


\begin{tabular}{|c|c|c|c|c|}
\hline & \multicolumn{2}{|c|}{ Pearson r correlations } & \multicolumn{2}{|c|}{ Comparison of means } \\
\hline & BU & ECU & BU & ECU \\
\hline Overall green building & (c) & $0.55(p=0.05)$ & $t=6.56(p<0.001)$ & $t=4.42(p=0.001)$ \\
\hline Sustainable sites & $0.43(p=0.05)$ & $0.81(p=0.001)$ & $t=1.95(p=0.06)$ & $(")$ \\
\hline Water efficiency & (") & $0.86(p<0.001)$ & (") & (i) \\
\hline Energy and atmosphere & (7) & $0.56(p=0.05)^{\prime}$ & $t=2.11(p<0.05)$ & (1) \\
\hline Materials and resources & (9) & $0.50(p=0.08)$ & (7) & (7) \\
\hline Indoor environmental quality & $(7)$ & $0.69(p=0.09)$ & (9) & (") \\
\hline Innovation in design & (i) & $0.80(p=0.001)$ & $t=2.05(p=0.06)$ & 17 \\
\hline Regional prionty & in & $0.86(p<0.001)$ & $t=3.54(p=0.01)$ & (i) \\
\hline
\end{tabular}

Table 7. Comparison of students' evaluations of their learning in other courses in interior architecture curricula and in the workshop.

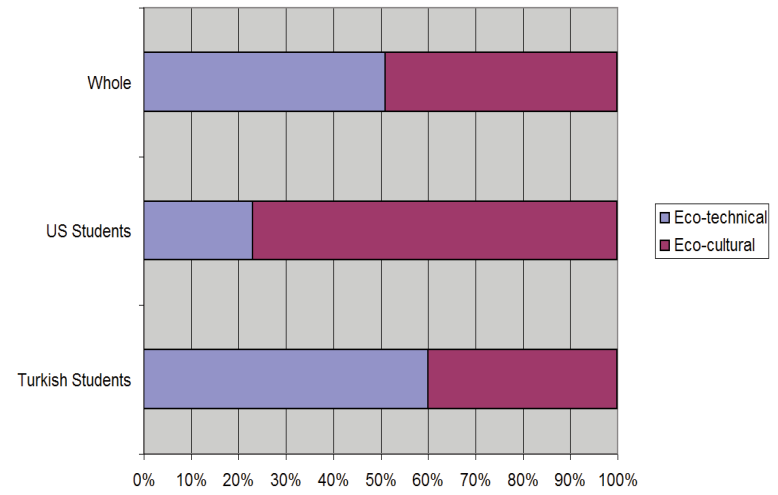

Figure 7. Students' preferences for eco-technical and ecocultural approaches in the workshop

correlation coefficients were calculated. The results indicated that while ECU students' evaluation of their learning in other courses and that in the workshop correlated significantly for all of the items, there was only one significant correlation in BU students' evaluations. Comparison of mean scores in students' evaluations of their learning in other courses and in the workshop revealed that there was no statistically significant difference in the ECU group. On the other hand, BU students' evaluations of their learning in the workshop were significantly more positive for several aspects of green building (Table 1).

The participants were asked about their choices for eco-technical or eco-cultural approaches in the design processes. The results indicated a significant difference between BU and ECU students. While there was a balanced distribution of these approaches in the whole sample, ECU students were more likely to adopt an ecocultural approach in their design proposals than BU students were $\left(\square^{2}=5.35, d f=1, p<0.05\right)$ (Figure 7).

\begin{tabular}{lcc}
\hline & $\mathrm{n}$ & $\%$ \\
\hline Required lecture & 21 & 38.2 \\
Required studio & 20 & 36.4 \\
Elective studio & 19 & 34.5 \\
Elective lecture & 18 & 32.7 \\
Required scientific lab & 9 & 16.4 \\
Elective scientific lab & 9 & 16.4 \\
Total: 55 & & 100 \\
\hline
\end{tabular}

Table 2. Students' preferences for types of courses on green building design

\begin{tabular}{lcc}
\hline & $\mathrm{n}$ & $\%$ \\
\hline Year 3 & 45 & 82 \\
Year 4 & 26 & 47 \\
Year 2 & 22 & 40 \\
Total: 55 & & 100 \\
\hline
\end{tabular}

Table 3. Students' opinions about at what level in interior architecture education green building design solutions should be required.

Students' opinions about integrating green building design with interior architecture education

In one of the two phased questions, all of the students $(100 \%)$ agreed that green building design is important in interior architecture education and in the following phase they underlined the level of importance attributed to green building design in interior architecture education as high $(X=4.44, S D=0.57, t=18.70, p<$ $0.001)$. Ninety-six percent of the participants reported that they would be interested in more courses on green building design in the curriculum. Students' preferences for different types of courses showed that while required and elective lecture and studio courses were almost equally preferred, scientific lab courses, either required or elective, were not much favored by the students (Table 2).

The participants were also asked to indicate their opinions about at what level in interior architecture education green building design solutions should be required. They could choose multiple studio levels. The results are presented in Table 3.

\section{DISCUSSION AND CONCLUSIONS}

This study provided insights into several issues related to sustainable and green building education in a global context. The results revealed a gap between Turkish and the US students' green building learning in interior architecture education in favor of the latter. This is largely due to the fact that, for the time being, all educational, academic and practical green building efforts in Turkey (and in most of the developing countries alike) depend upon self-motivation of interested parties, schools and companies in the absence of standards and regulations.

The study also showed that the global teamwork experience in the workshop facilitated alleviating the existing situation: both groups' evaluations of their learning in the workshop were almost equal and highly positive. The proposed model for the green building workshop was proved to be useful as indicated by the students' responses to the survey. The online collaboration of geographically distant students and instructors promoted peer-to-peer interaction, student-centric learning, and exchange of technical and cultural information. Furthermore, the complementary use of several tools with different capabilities created a positive learning environment (Pektas and Gurel, in press). This cooperation also fostered share of information regarding local solutions to sustainability that may be transferable. As a result, a majority of participants reported that the workshop stimulated their interest in environmentally responsive design, increased their understanding of green building concepts, and affected the way they would 
approach to interior architecture in their prospective professional practices. These findings suggest that international collaborative studies may further be used to bridge the gap between developing and developed countries in sustainable building education.

The LEED evaluation system provided a convenient framework to address several aspects of green building design. Kaatz et al. (2006) discuss that there may be three outcomes of sustainability assessment: integration, transparency and accessibility, and collaborative learning. Sustainable design is a complex issue even for the LEED Accredited Professionals who not only pass the exam but also work as associates to the previously approved experts for three years. In this workshop, there were instructors from different professional backgrounds (i.e. architects and interior architects) and some of them were holding LEED AP certificate, whereas some of them were not educated in LEED but enthusiastic about learning green building design. The LEED system provided all the related parties with a shared model of sustainability during the workshop. Hence, this study reaffirms the importance of the efforts of developing countries who are working on having their own green building assessment systems.

It was also observed that the balanced emphasis on eco-technical and eco-cultural approaches in the workshop benefited both groups. While Turkish students became acquainted with the LEED assessment system, the US students learned about sustainable solutions in Turkish vernacular architecture. ECU students had been mostly studying on the real life projects in eastern North Carolina and learning the design problem solving according to the climatic and ecological circumstances of this region. However, they were exposed to six different climatic regions and vernacular architecture examples for these regions in Turkey for the same design problem in the workshop. Later, they also recognized that they should be recommending different solutions to help their acquaintance earn LEED points according to these climatic changes.

All of the students participated in the survey viewed the integration of green building with education as an issue of high importance. The students reported that sustainability should be integrated to curricula and ideally penetrate into all courses. Integrating green building issues into a design studio in this study was especially appreciated. A majority of students stated that green building design solutions should be required at the third year (junior) and fourth year (senior) studios when students have acquired sufficient knowledge and skills which correspond to complexities of sustainable design.

In summary, this study indicated differences in students' green building learning experiences in a developing and a developed country and suggested about how to integrate sustainability into design education. Considering the lack of research on green building design education, we believe that this study will fill a research gap and trigger further comparative studies.

\section{ACKNOWLEDGEMENTS}

The authors would like to thank the students and instructors who participated in the international workshop.

\section{REFERENCES}

AHN, Y. H., HYUKSOO, K., PEARCE, A. R. and WELLS, J. G. 2009, The systematic course development process: Building a course in sustainable construction for students in the USA, Journal of Green Building, 4:1, 169-182.

ALI, H. H. and AL NSAIRAT, S. F. 2009, Developing a green building assessment tool for developing countries-case of Jordan, Building and Environment, 44:5, 1053-64.

CEDBIK 2007, Homepage of CEDBIK. Accessed May 12, 2012. http://www.cedbik.org/sayfalar.asp?KatlD $=2 \& I D=19$

CIDA 2013, Accredited Programs. Accessed June 14, 2013. http://accredit-id.org/accredited-programs

CIDA 2011 , Professional Standards, 2011. Accessed February 04, 2012. http://accredit-id.org/wp content/uploads /2010/03/

Professional-Standards-2011.pdf.

CRADLE TO CRADLE TASK FORCE 2005, Endorsing the C2C design paradigm (Task force proposal presented at the annual business meeting of the Interior Design Educators Council, Savannah, $\mathrm{GA})$.

GIBBERD, J. 2003, Integrating Sustainable Development into Briefing and Design Processes of Buildings in Developing Countries: An Assessment Tool, PhD dissertation, University of Pretoria.

GUREL, M. 2010, Explorations in teaching sustainable design: A studio experience in interior architecture, International Journal of Art and Design Education, 29:2, 184199.

GUY, S. and FARMER, G. 2001, Reinterpreting sustainable architecture: The place of technology, Journal of Architectural Education, 54:3, 140-148.

HOFFMAN, A. J. and HENN, R. 2008, Overcoming the social and psychological barriers to green building, Organization \& Environment, $21: 4,390-419$.

IFI 2011, Homepage of IFI. Accessed May 12, 2012.http://www.ifiworld.org/\#Homepage

JONES, L. 2008, Environmentally Responsible Design: Green and Sustainable Design for Interior Designers, John Wiley \& Sons Inc., New York.

JUNYENT, M. and GEL' DE CIURANA, A. M. 2008, Education for sustainability in university studies: A model for reorienting the curriculum, British Educational Research Journal, 34:6, 763782.

KAATZ, E., ROOT, D. S., BOWEN, P. A. and HILL, R. C. 2006, Advancing key outcomes of sustainability building assessment, Building Research and Information, 34:4, 308-320.

KARAKAYA, A. F. and PEKTAS, S. T. 2007, A framework for webbased education systems supporting interdisciplinary design collaboration, METU Journal of the Faculty of Architecture, 24:2, 137 . 148.

KRISTOF, A. L., BROWN, K. G., SIMS, H. P. and SMITH, K. A. 1995, The virtual team: A case study and inductive model, Advances in Interdisciplinary Studies of Work Teams: Knowledge Work in Teams, 2, 229-53. 
LARSSON, N. K., and COLE, R. J. 2001, Green building challenge: The development of an idea, Building Research \& Information, 29:5, 336-45.

LEED 2009, LEED for New Construction v2009, USGBC, Washingtong, DC.

O'REILLY, H., and SYMKO, T. 2008, Reaching across borders: Sustainability initiatives within and beyond the resort community of Whistler, in: D. K. Alper, J. C. Day, and J. Loucky (Eds) Transboundary Policy Challenges in the Pacific Border Regions of North America, 267-288, University of Calgary Press, Calgary.

OLGYAY, V. 1992, Design with Climate: Bioclimatic Approach to Architectural Regionalism. $2^{\circ}$ ed., Van Nostrand Reinhold, New York.

PEKTAS, S. T. 2007, A structured analysis of CAAD education, Open House International, 32:2, 46-54.

PEKTAS, S. T. and GUREL, M. O. In press, Blended learning in design education: An analysis of students' experiences within the disciplinary differences framework, Australasian Journal of Educational Technology.

REED, W. G. and GORDON, E. B. 2000, Integrated design and building process: What research and methodologies are needed, Building Research \& Information, 28:5-6, 325-337.

SATHAYE, J., SHUKLA, P. R. and RAVINDRANATH, N. H. 2006, Climate change, sustainable development and India: Global and national concerns, Current Science, 90:3, 314-25.

SENSOY, S., DEMIRCAN, M., ULUPINAR, Y. and BALTA, I. 2008, Climate of Turkey by Turkish State Meteorological Service. Accessed 19 June, 2013. http://www.mgm.gov.tr/files/en-US/climateofturkey.pdf

STIEG, C. 2006, The sustainability gap, Journal of Interior Design, $32: 1$, vii-xxi.

TODD, J. A., CRAWLEY, D., GEISSLER, S. and LINDSEY, G. 2001, Comparative assessment of environmental performance tools and the role of the green building challenge, Building Research \& Information, 29:5, 324 335.

UNAL, Y., KINDAP, T. and KARACA, M. 2003, Redefining the climate zones of Turkey using cluster analysis, International Journal of Climatology, 23, 1045-1055.

UNITED NATIONS 2004, Agenda 21 Chapter 36: Promoting Education, Public Awareness and Training. Accessed 25 June 2013. http://sustainabledevelopment.un.org/content/documents/Agenda2 1.pdf

Author(s):

Şule Taşlı Pektaş (Corresponding author)

Department of Architecture, Bilkent University 06800, Bilkent/Ankara, Turkey

Email: tasli@bilkent.edu.tr

\section{N. Şule Aybar}

Department of Interior Architecture and Environmental Design Bilkent University 06800, Bilkent/Ankara, Turkey

Email:sule@bilkent.edu.tr

N. Yaprak Savut

Department of Interior Architecture and Environmental Design, Bilkent University 06800, Bilkent/Ankara, Turkey

Email: nyaprak@bilkent.edu.tr

\section{Hunt McKinnon}

Department of Interior Design and Merchandising East Carolina University Greenville, NC 27858, USA

Email:mckinnonw@ecu.edu 